\title{
Pengembangan Media Pembelajaran Jujitsu Newaza Berbasis Aplikasi Articulate Storyline
}

\author{
Adz Dzaria Nisa Solecha*, Ari Wibowo Kurniawan \\ Universitas Negeri Malang, Jl. Semarang No. 5 Malang, Jawa Timur, Indonesia \\ *Penulis korespondensi, Surel: nisasolecha@gmail.com
}

Paper received: 1-10-2021; revised: 19-10-2021; accepted: 25-10-2021

\begin{abstract}
This research and development aims to develop learning tools for jujitsu newaza techniques based on articulate storylines in the form of an application used for learning media for newaza jujitsu for PBJI athletes and coaches in Blitar Regency and also useful as a reference and development for further research. The development method used in this research is the Research and Development (R\&D) method or development research. The small group trial subjects involved 9 PBJI athletes in Blitar Regency and the large group trial subjects involved 13 PBJI athletes in Blitar Regency. The results of the analysis of the experts who have done the validity, the percentage of the evaluation of coaching experts is 91 percent which means very valid, the results of the evaluation of media experts are 96 percent which means very valid, the results of the evaluation of the jujitsu experts are 77 percent which means very valid, the results of the group trial small obtained 82 percent which means very valid, the results of large group trials obtained 90 percent which means very valid. Based on the analysis of these data, it can be concluded that the development product of learning media jujitsu newaza (fights below) based on the articulate storyline application can be said to be "suitable for use" for the newaza learning media for PBJI Blitar Regency. It is recommended that in learning jujitsu, the newaza technique based on the articulate storyline is only used in the newaza material before learning newaza in the core activities of learning newaza.
\end{abstract}

Keywords: learning media; articulate storyline; jujitsu newaza

\begin{abstract}
Abstrak
Penelitian dan pengembangan ini bertujuan untuk mengembangkan perangkat pembelajaran Teknik jujitsu newaza yang berbasis articulate storyline yang berupa sebuah aplikasi yang digunakan untuk media pembelajaran jujitsu newaza, memberikan kemudahan belajar secara visualisasi bagi atlet dan memberikan akses yang mudah terhadap materi newaza untuk atlet dan pelatih PBJI Kabupaten Blitar dan juga bermanfaat menjadi rujukan dan pengembangan untuk penelitian selanjutnya. Metode pengembangan yang digunakan dalam penelitian ini adalah metode Research and Development (R\&D) atau penelitian pengembangan. Subjek uji coba kelompok kecil melibatkan 9 atlet PBJI Kabupaten Blitar dan subjek uji coba kelompok besar melibatkan 13 atlet PBJI Kabupaten Blitar. Hasil analisis dari para ahli yang sudah melakukan validitas maka diperoleh persentase evaluasi ahli kepelatihan 91 persen yang berarti sangat valid, hasil evaluasi ahli media diperoleh 96 persen yang berarti sangat valid, hasil evaluasi ahli jujitsu diperoleh 77 persen yang berarti sangat valid, hasil uji coba kelompok kecil diperoleh 82 persen yang berarti sangat valid, hasil uji coba kelompok besar diperoleh 90 persen yang berarti sangat valid. Berdasarkan analisis data tersebut, maka dapat disimpulkan bahwa produk pengembangan media pembelajaran jujitsu newaza (perkelahian bawah) berbasis aplikasi articulate storyline dapat dikatakan "layak digunakan" untuk media pembelajaran newaza untuk PBJI Kabupaten Blitar. Disarankan dalam pembelajaran jujitsu teknik newaza berbasis articulate storyline ini hanya digunakan pada materi newaza sebelum melakukan pembelajaran newaza pada kegiatan inti pembelajaran newaza.
\end{abstract}

Kata kunci: media pembelajaran; articulate storyline; jujitsu newaza 


\section{Pendahuluan}

Olahraga saat ini sudah berkembang di masyarakat umum untuk memenuhi kebutuhan kebugaran jasmani, kesehatan, hiburan, dan untuk mencapai prestasi. Salah satu yang terpenting dalam olahraga yaitu olahraga prestasi yang sangat dibutuhkan sekarang. Di Dalam pembelajaran sangat penting menggunakan media pembelajaran untuk menunjang tercapainya tujuan pembelajaran dengan efektif. Menurut Nurfauziah (2016), dalam jurnalnya yang menyatakan bahwa media pembelajaran dapat membantu peserta didik dalam memahami dan mengerti tentang suatu informasi sehingga peserta didik dapat lebih mudah untuk menguasai keterampilan/bakat yang akan dipelajarinya dalam pembelajaran. Menurut Nur (2017) media pembelajaran merupakan salah satu alat untuk mencapai tujuan pembelajaran yang akan dicapai. Yaitu dengan memanfaatkan media sebagai alat untuk menyampaikan pesan ataupun informasi dari guru kepada siswa sehingga dapat tercapai tujuan pembelajaran. Dari pendapat ahli diatas dapat disimpulkan bahwa media pembelajaran adalah salah satu alat yang bisa digunakan oleh guru untuk menyampaikan materi kepada siswa, sehingga proses belajar mengajar menjadi menarik. Dapat disimpulkan bahwa media pembelajaran adalah alat yang digunakan guru untuk mengajar sehingga dapat menyampaikan materi kepada siswa dengan mudah dalam proses pembelajaran. Alat bantu tersebut digunakan untuk membuat pengalaman yang lebih nyata, memotivasi dalam belajar, menarik minat siswa, dan memperkuat daya serap belajar siswa.

Media pembelajaran yang digunakan oleh peneliti berupa aplikasi yaitu aplikasi articulate storyline merupakan variasi bentuk pembelajaran melalui media berbasis komputer yang dapat digunakan dalam penyampaian pembelajaran dalam latihan. Aplikasi pembelajaran berbasis articulate storyline ini memiliki keunggulan yang sangat lengkap dan mudah untuk digunakan para atlet. Aplikasi pembelajaran berbasis articulate storyline ini menyajikan berbagai materi pembelajaran untuk latihan atlet dirumah yang berbentuk video,gambar, dan tahapan materi pembelajaran untuk menunjang proses suksesnya dalam bertanding. Articulate Storyline adalah perangkat lunak yang berfungsi sebagai media komunikasi atau bisa untuk presentasi yang digunakan dalam pembelajaran. Media pembelajaran yang menggunakan software articulate storyline tidak kalah menarik dengan media interaktif lainnya. Dengan aplikasi articulate storyline tersebut sangat memungkinkan bahwa atlet akan lebih tertarik dan meningkatkan daya serap saat proses pembelajaran berlangsung (Darnawati et al., 2019; Pratama, 2018; Purnama \& Asto, 2014; Yumini \& Rakhmawati, 2015).

Club beladiri jujitsu adalah salah satu klub yang bergerak dibidang prestasi yang memiliki tujuan yang sama yaitu membantu atlet dalam berlatih dan tercapainya tujuan pembelajaran untuk mencapai puncak prestasi. Jujitsu merupakan olahraga yang banyak digemari oleh berbagai kalangan karena sifatnya yang fleksibel dan kompleks. Salah satu pertandingan yang ada dalam jujitsu ada newaza. Di dalam newaza terdapat berbagai macam teknik yaitu terdiri atas offense/serangan yang berupa bantingan dan sapuan dan teknik defense/ bertahan yaitu berupa teknik dasar yang memanfaatkan kelemahan lawan untuk mendapatkan kuncian atau memancing lawan menuju arah kuncian yang mematikan.

Seiring berkembangnya zaman dan teknologi yang semakin modern, maka teknologi bisa dijadikan alat untuk kegiatan sehari-hari, bahkan untuk proses pembelajaran newaza khususnya di saat pembelajaran daring seperti saat ini. Untuk menunjang latihan newaza agar lebih menarik dalam proses pembelajaran, maka teknik-teknik dalam pembelajaran newaza dikemas di dalam aplikasi bernama articulate storyline yang telah dijelaskan oleh peneliti. 
Dengan adanya media pembelajaran berupa aplikasi ini akan membantu pelatih dalam proses pembelajaran atau latihan secara daring, selain itu atlet juga akan tertarik saat materi newaza diajarkan karena di dalam aplikasi juga disajikan gambar, video, musik yang akan membuat atlet antusias mengikuti dan mempraktikkan teknik newaza di rumah secara daring. Berdasarkan penelitian sebelumnya menurut Gilar (2014), yang menggunakan media dalam latihan. Pada penelitian ini yaitu berfokus pada latihan gerak kaki yang digunakan pada teknik bantingan. Produk pengembangan berupa media untuk latihan gerak kaki saat melakukan teknik bantingan layak untuk digunakan. Menggunakan media banner untuk latihan, Penulis berpendapat bahwa media banner dirasa kurang menarik minat atlet dalam pembelajaran newaza, atlet lebih tertarik dengan adanya gambar,video,teks,audio, yang digabungkan menjadi satu bagian yaitu aplikasi.

Dan dari hasil analisis kebutuhan yang peneliti lakukan pada tanggal 16 agustus 2020 diperoleh data sebagai berikut : a). Jumlah responden berjumlah 22 orang yang terdiri dari atlet dan 2 orang pelatih jujitsu PBJI Kabupaten Blitar. b). Terdapat 72,5\% dari 10 responden bahwa materi yang disajikan masih sulit untuk dipahami, c) Dari 10 responden yang terdiri dari atlet dan pelatih jujitsu PBJI Kabupaten Blitar terdapat 77,5\% menguasai teknik newaza, d). Sebanyak $85 \%$ atlet dan pelatih membutuhkan suatu media pembelajaran baru agar latihan semakin menarik, e). Sebanyak 87,5\% atlet dan pelatih jujitsu PBJI Kabupaten Blitar setuju apabila dikembangkan pembelajaran berbasis aplikasi articulate storyline yang mudah dan praktis.Dengan menggunakan aplikasi articulate storyline terdapat beberapa aspek mengapa penelitian ini penting untuk dilakukan yaitu aplikasi articulate storyline memudahkan pengajar dalam penyampaian materi pembelajaran dan tentunya juga memudahkan atlet dalam memahami materi yang disampaikan. Ditampilkan juga video untuk memperjelas atlet dalam memahami suatu gerakan dan juga audio agar pembelajaran tidak monoton dan dijelaskan secara bertahap setiap gerakan. Terdapat juga soal-soal guna mengevaluasi seberapa jauh tingkat kepahaman atlet pada materi yang disampaikan. Dengan adanya produk pengembangan perangkat ini diharapkan atlet menjadi lebih aktif di dalam latihan maupun diluar dan juga bisa meningkatkan motivasi belajar siswa guna untuk mendapatkan hasil yang maksimal dalam pertandingan yang akan datang.

Dengan adanya masalah tersebut, maka peneliti memecahkan masalah dengan cara mengembangkan media pembelajaran aplikasi tentang newaza untuk PBJI Kabupaten Blitar. Variasi teknik dasar newaza dikemas dalam sebuah aplikasi yang bisa digunakan untuk pembelajaran khususnya pada saat daring yaitu sebanyak 6 teknik. Berdasarkan latar belakang peneliti tertarik untuk melakukan penelitian dan pengembangan yang berjudul "Pengembangan Media Pembelajaran Jujitsu Newaza (Perkelahian Bawah) Berbasis Aplikasi Articulate Storyline". Articulate storyline merupakan sebuah program yang diciptakan untuk mendukung para perancang pembelajaran modern di era teknologi berbasis digital mulai dari kalangan pemula hingga profesional sebagai penyampaian informasi atau komunikasi yang lebih interaktif kepada pengguna (Setyaningsih et al., 2020).

Tujuan penelitian ini adalah untuk mengembangkan sebuah produk berupa aplikasi dari articulate storyline berisi gambar, video penjelasan, teks, dan audio yang dapat digunakan sebagai media pembelajaran newaza yang berisi teknik newaza untuk mengatasi beberapa masalah dalam pembelajaran newaza khususnya pada saat pembelajaran daring yang dikarenakan oleh adanya pandemi virus covid-19. Dan menjadikan atlet lebih termotivasi dan semangat dalam berlatih. 


\section{Metode}

Dalam penelitian pengembangan ini menggunakan metode Research and Development (R\&D) atau penelitian pengembangan dengan langkah-langkah sebagai berikut: (1) Analisis yaitu mengumpulkan data yang disebut analisis kebutuhan dengan cara membagikan angket dan wawancara, (2) Desain merupakan tahap perencanaan produk yaitu mengumpulkan bahan-bahan yang dibutuhkan yang nantinya akan dikembangkan, (3) Pengembangan yaitu tahap mengembangkan produk media pembelajaran newaza dengan cara mengambil video, merekam audio, memasukkan materi, mengedit dan sebagainya. Untuk meninjau validasi dari produk pengembangan pembelajaran newaza akan dilakukan oleh ahli kepelatihan, ahli media, dan ahli jujitsu yang bertujuan untuk dapat memperbaiki kekurangan produk, (4) Implementasi yaitu tahap uji coba dan (5) Evaluasi digunakan untuk mengetahui seberapa layaknya produk yang dikembangkan oleh peneliti.

Dalam tahap uji coba produk terdapat (1) Desain uji coba, (2) Subjek uji coba, (3) Jenis data, (4) Instrumen pengumpulan data, (5) teknik analisis data. Desain uji coba terdapat evaluasi ahli yang dilakukan oleh 3 ahli yaitu ahli kepelatihan, ahli media, dan ahli jujitsu. Kemudian uji coba kelompok kecil, dan uji coba kelompok besar. Subjek ujicoba untuk kelompok kecil yaitu 9 atlet PBJI Kabupaten Blitar, sedangkan subjek uji coba kelompok besar yaitu 13 atlet PBJI Kabupaten Blitar, subjek evaluasi para ahli yaitu 1 orang kepelatihan, 1 orang ahli media, dan 1 orang ahli jujitsu.

Dalam penelitian ini data yang diperoleh berupa data kualitatif dan kuantitatif. Data kualitatif diperoleh dari hasil evaluasi para ahli dan wawancara dengan pelatih jujitsu PBJI Kabupaten Blitar yang berupa saran-saran dan penjelasan agar produk bisa menjadi lebih baik. Sedangkan data kuantitatif diperoleh dari hasil uji coba kelompok kecil dan hasil uji coba kelompok besar yang berupa angka. Variabel yang digunakan dalam penelitian ini berupa media pembelajaran teknik jujitsu newaza (perkelahian bawah) berbasis aplikasi articulate storyline.

Instrumen yang digunakan dalam penelitian pengembangan ini yaitu observasi awal untuk analisis kebutuhan berupa angket yang diisi langsung oleh atlet PBJI Kabupaten Blitar, angket untuk uji coba kelompok kecil dan uji coba kelompok besar, serta angket untuk para ahli yaitu ahli kepelatihan, ahli media, dan ahli jujitsu.

Teknik analisis data yang digunakan dalam penelitian dan pengembangan media pembelajaran newaza berbasis articulate storyline untuk PBJI Kabupaten Blitar menggunakan statistik deskriptif. Tahap analisis data, peneliti menggunakan statistik deskriptif, data terkumpul dengan teknik pengukuran skala likert, dimana bertujuan mengukur sikap, persepsi serta gagasan individu dan kelompok mengenai kejadian sosial (Sugiyono, 2015). Instrumen skala likert memiliki kategori jawaban dari sangat setuju hingga tidak setuju. Pada kebutuhan analisis data kuantitatif jawaban telah ditetapkan skor seperti yang disajikan pada tabel 1 . 
Tabel 1. Skala Evaluasi Pertanyaan

\begin{tabular}{clcc}
\hline No. & Keterangan & Jawaban & Skor \\
\hline 1. & Sangat Setuju & A & 4 \\
2. & Setuju & B & 3 \\
3. & Ragu-ragu & C & 2 \\
4. & Tidak Setuju & D & 1 \\
\hline
\end{tabular}

Rumus yang digunakan dalam mengolah data dalam bentuk analisis deskriptif kuantitatif persentase, sebagai berikut:

$V=\frac{T S E V}{S-\max } \times 100 \%$

Pada rumus $1, \mathrm{~V}$ adalah validitas, TSEV adalah total skor empirik validator, $\mathrm{S}$-max adalah skor maksimal yang diharapkan, sedangkan $100 \%$ adalah bilangan konstanta. Selanjutnya agar memudahkan pada perolehan ketepatan data hasil analisis persentase, maka diklasifikasikan dengan rentangan persentase perolehan yang didapatkan. Menurut (Irawan \& Japarianto, 2013) klasifikasi persentase seperti yang disajikan pada tabel 2 .

Tabel 2. Parameter Status Produk

\begin{tabular}{lll}
\hline \multicolumn{1}{c}{ Kriteria } & \multicolumn{1}{c}{ Keterangan } & \multicolumn{1}{c}{ Makna } \\
\hline $75,01 \%-100,00 \%$ & Sangat Valid & Digunakan tanpa revisi \\
$50,01 \%-75,00 \%$ & Cukup Valid & Digunakan dengan revisi kecil \\
$25,01 \%-50,00 \%$ & Tidak Valid & Tidak dapat digunakan \\
$00,00 \%-25,00 \%$ & Sangat Tidak Valid & Terlarang digunakan \\
\hline
\end{tabular}

\section{Hasil dan Pembahasan}

\subsection{Hasil}

Pembahasan kali ini tentang produk pengembangan, penyajian data yang terdiri dari analisis kebutuhan, validasi para ahli, uji coba produk kelompok kecil, dan uji coba produk kelompok besar, serta revisi produk.

\subsubsection{Ahli Kepelatihan}

Tabel 3. Hasil Analisis Data Ahli Kepelatihan

\begin{tabular}{clcc}
\hline No. & Aspek & \% & Kategori \\
\hline 1 & Ketepatan & 88 & Sangat Valid \\
2 & Kemudahan & 94 & Sangat Valid \\
\hline Rata-Rata & 91 & Sangat Valid \\
\hline
\end{tabular}

Data pertama yaitu data kuantitatif yang diperoleh dari evaluasi ahli kepelatihan mengenai produk media pembelajaran newaza berbasis articulate storyline untuk PBJI Kabupaten Blitar dengan tingkat ketepatan $88 \%$ yang berarti sangat valid, dan kemudahan 
94\% yang berarti sangat valid. Berdasarkan dari aspek-aspek tersebut maka dapat disimpulkan bahwa produk pengembangan media pembelajaran ini memperoleh persentase 91\% dan dikatakan sangat valid.

\subsubsection{Ahli Jujitsu}

Tabel 4. Hasil Analisis Data Ahli Jujitsu

\begin{tabular}{cccc}
\hline No. & Aspek & \% & Kategori \\
\hline 1 & Kemudahan & 75 & Cukup Valid \\
2 & Ketepatan & 81 & Sangat Valid \\
\hline Rata-Rata & 78 & Sangat Valid \\
\hline
\end{tabular}

Data kedua yaitu data kuantitatif yang diperoleh dari evaluasi ahli jujitsu mengenai produk media pembelajaran newaza berbasis articulate storyline untuk PBJI Kabupaten Blitar dengan tingkat kemudahan $75 \%$ dan ketepatan $81 \%$ yang berarti sangat valid. Berdasarkan dari aspek-aspek tersebut maka dapat disimpulkan bahwa produk pengembangan media pembelajaran ini memperoleh persentase $78 \%$ dan dikatakan sangat valid.

\subsubsection{Ahli Media}

Tabel 5. Hasil Analisis Data Ahli Media

\begin{tabular}{cccc}
\hline No. & Aspek & $\mathbf{\%}$ & Kategori \\
\hline 1 & Kemenarikan & 100 & Sangat Valid \\
2 & Kesesuaian & 95 & Sangat Valid \\
3 & Ketepatan & 100 & Sangat Valid \\
\hline \multicolumn{2}{l}{ Rata-Rata } & 98 & Sangat Valid \\
\hline
\end{tabular}

Data ketiga yaitu data kuantitatif yang diperoleh dari evaluasi ahli media mengenai produk media pembelajaran newaza berbasis articulate storyline untuk PBJI Kabupaten Blitar dengan tingkat kemenarikan 100\% yang berarti sangat valid, kesesuaian 95\% yang berarti sangat valid dan ketepatan $100 \%$ yang berarti sangat valid. Berdasarkan dari aspek-aspek tersebut maka dapat disimpulkan bahwa produk pengembangan media pembelajaran ini memperoleh persentase $98 \%$ dan dikatakan sangat valid.

\subsubsection{Uji Coba Kelompok Kecil}

Tabel 6. Hasil Analisis Uji Coba Kelompok Kecil

\begin{tabular}{llrc}
\hline No. & Aspek & $\mathbf{\%}$ & Kategori \\
\hline 1 & Kejelasan & 82 & Sangat Valid \\
2 & Kemudahan & 82 & Sangat Valid \\
3 & Kemenarikan & 84 & Sangat Valid \\
4 & Ketepatan & 81 & Sangat Valid \\
\hline \multicolumn{2}{l}{ Rata-Rata } & 82 & Sangat Valid \\
\hline
\end{tabular}

Data keempat yaitu data kuantitatif dari hasil uji coba kelompok kecil oleh 9 atlet PBJI Kabupaten Blitar mengenai produk media pembelajaran newaza berbasis articulate storyline 
untuk PBJI Kabupaten Blitar. Diperoleh hasil dengan tingkat kejelasan 82\% yang berarti sangat valid, kemudahan $82 \%$ yang berarti sangat valid, kemenarikan $84 \%$ yang berarti sangat valid, dan ketepatan $81 \%$ yang berarti sangat valid. Berdasarkan dari aspek-aspek tersebut maka dapat disimpulkan bahwa produk pengembangan media pembelajaran ini memperoleh persentase $82 \%$ dan dikatakan sangat valid.

\subsubsection{Uji Coba Kelompok Besar}

Tabel 7. Hasil Analisis Uji Coba Kelompok Besar

\begin{tabular}{llrc}
\hline No. & \multicolumn{1}{c}{ Aspek } & $\mathbf{\%}$ & Kategori \\
\hline 1 & Kejelasan & 91 & Sangat Valid \\
2 & Kemudahan & 88 & Sangat Valid \\
3 & Kemenarikan & 91 & Sangat Valid \\
4 & Ketepatan & 90 & Sangat Valid \\
\hline Rata-Rata & 90 & Sangat Valid \\
\hline
\end{tabular}

Data kelima yaitu data kuantitatif dari hasil uji coba kelompok besar oleh 13 atlet PBJI Kabupaten Blitar mengenai produk media pembelajaran newaza berbasis articulate storyline untuk PBJI Kabupaten Blitar. Diperoleh hasil dengan tingkat kejelasan 91\% yang berarti sangat valid, kemudahan $88 \%$ yang berarti sangat valid, kemenarikan $91 \%$ yang berarti sangat valid, dan ketepatan $90 \%$ yang berarti sangat valid. Berdasarkan dari aspek-aspek tersebut maka dapat disimpulkan bahwa produk pengembangan media pembelajaran ini memperoleh persentase $90 \%$ dan dikatakan sangat valid.

\subsection{Pembahasan}

Produk akhir penelitian ini berupa aplikasi media pembelajaran newaza berbasis articulate storyline untuk PBJI Kabupaten Blitar yang menggunakan aplikasi articulate storyline. Pengembangan media pembelajaran yang tepat dan menarik sangat dibutuhkan untuk menunjang tercapainya proses pembelajaran. Hasil penelitian Chotimah (2018), dalam jurnalnya menyatakan perangkat pembelajaran yang didesain secara menarik dan kreatif memberikan kemudahan pendidik untuk bisa menyampaikan materi yang mudah dipahami peserta didik serta mempengaruhi kemampuan minat belajar peserta didik.

Media yang dikembangkan oleh peneliti yaitu aplikasi articulate storyline. Articulate Storyline adalah perangkat lunak yang berfungsi sebagai media komunikasi atau bisa untuk presentasi yang digunakan dalam pembelajaran. Media pembelajaran yang menggunakan software articulate storyline tidak kalah menarik dengan media interaktif lainnya (Purnama \& Asto, 2014).

Aplikasi articulate storyline ini memiliki kemudahan dalam penggunaannya yang simple dan jelas, oleh karena itu peneliti menggunakan aplikasi ini untuk dikembangkan menjadi media pembelajaran newaza untuk atlet, aplikasi ini dapat membantu pelatih untuk menyampaikan teknik newaza yang sulit dipahami oleh atlet, ditambah kondisi saat ini yang banyak waktu dirumah. Di dalam aplikasi juga terdapat gambar, video, musik, dan 6 teknik newaza agar tujuan latihan dapat tercapai dengan maksimal. 
Jujitsu merupakan olahraga prestasi yang dibina untuk mencetak prestasi yang membanggakan. Seperti yang dikemukakan oleh Kurniawan (2014) bahwa olahraga prestasi adalah olahraga yang membina dan mengembangkan olahragawan secara terencana, berjenjang, dan berkelanjutan melalui kompetisi untuk mencapai prestasi dengan dukungan ilmu pengetahuan dan teknologi (Iptek).

Di dalam newaza terdapat berbagai macam teknik yaitu terdiri dari offense/serangan yang berupa bantingan dan sapuan dan teknik defense/ bertahan yaitu berupa teknik dasar yang memanfaatkan kelemahan lawan untuk mendapatkan kuncian atau memancing lawan menuju arah kuncian yang mematikan Noors (2000). Teknik yang dibahas peneliti sebanyak 6 teknik newaza yaitu: (1) Knee on Belly, (2) Take down, (3) Armbar, (4) Triangle choke, (5) Back control, (6) Passing guard. Setiap video teknik newaza terdapat penjelasan per tahap agar atlet mudah untuk memahaminya.

Arwanda, Irianto \& Andriani (2020), dalam jurnalnya menunjukan bahwa pengembangan pembelajaran menggunakan articulate storyline untuk ekstrakurikuler jujitsu memberikan pengaruh yang sangat baik terhadap motivasi dan minat belajar siswa, guru memberikan respon sangat baik terhadap pengembangan tersebut dikarenakan menjadi referensi dan membantu guru dalam menyampaikan pembelajaran yang lebih menarik dan kreatif. Sehingga articulate storyline ini adalah salah satu dari beberapa media pembelajaran dapat digunakan, ini memberi pengaruh yang positif kepada peserta didik di saat pembelajaran online dan offline. Karena bentuk akhir dari produk ini adalah aplikasi yang dapat dioperasikan melalui smartphone, laptop dan web sehingga memberikan kemudahan kepada pengajar serta peserta didik dalam pelaksanaan pembelajaran. Selaras menurut lainnya ( Pamungkas, I. A. \& Dwiyogo, W. D 2020), menyatakan bahwa penelitian menghasilkan produk pengembangan media pembelajaran berbasis mobile learning untuk aktivitas kesegaran jasmani siswa SMKN 1 Batu. Adapun hasil dari penelitian menunjukan nilai yang maksimal atau indeks Amat.

Dengan adanya produk media pembelajaran berupa aplikasi yang telah terdapat teknik newaza, serta evaluasi dari para ahli dan hasil pengerjaan soal dan nilai akan diketahui oleh atlet. Oleh karena itu produk ini akan sangat memudahkan pelatih dalam menyampaikan materi newaza. Selain itu atlet juga akan tertarik untuk belajar newaza dengan semangat yang tinggi dan tidak mudah bosan karena adanya produk media pembelajaran yang dikembangkan oleh peneliti.

Hasil validasi ahli terdapat beberapa saran yaitu saran dari ahli kepelatihan yaitu masukkan juga tingkatan sabuk tradisional dan perlu ditambahkan teknik yang mendapatkan poin, seperti knee on belly, sweep, mount dan back mount. Saran dari ahli kepelatihan tersebut telah diperbaiki oleh peneliti pada produk media pembelajaran newaza berbasis articulate storyline untuk PBJI Kabupaten Blitar.

Produk pengembangan ini lebih ditekankan pada materi teknik newaza yang telah dikemas lebih menarik dalam aplikasi articulate storyline dan dapat diakses melalui smartphone, link serta laptop. Dalam video pembelajaran sendiri telah memenuhi kriteria yang telah direvisi oleh para ahli yang harus diberikan kepada atlet dalam pembelajaran. Produk ini dapat dijadikan bahan ajar di dalam materi newaza sebelum dipraktikkan pada kegiatan pembelajaran di lapangan. 
Kelebihan aplikasi ini yaitu salah satunya articulate storyline digunakan dalam mempresentasikan informasi sesuai dengan tujuan pengguna (Pratama, 2018).Aplikasi articulate storyline sendiri memiliki kemudahan dalam penggunaannya oleh karena itu peneliti menggunakan aplikasi ini untuk dikembangkan menjadi media pembelajaran, aplikasi ini dapat menunjang pelatih untuk menyampaikan pembelajaran khususnya materi newaza agar pembelajaran newaza dapat berjalan dengan lancar.

Hasil produk pengembangan media pembelajaran newaza berbasis articulate storyline untuk PBJI Kabupaten Blitar telah melalui beberapa tahapan revisi dan diperoleh produk terbaik untuk layak digunakan. Produk pengembangan memiliki beberapa kelebihan yaitu: (1) Produk dibuat dengan aplikasi Articulate Storyline yang dapat digunakan secara offline dan diinstall melalui hp android, (2) Berisi tentang teknik newaza dengan tahapan dibuat sejelas mungkin dan dikemas secara menarik, (3) Produk pengembangan ini dapat mempermudah atlet dalam latihan tambahan secara daring di rumah masing-masing.

\section{Simpulan}

Hasil dari penelitian dan pengembangan media pembelajaran jujitsu newaza berbasis articulate storyline dapat disimpulkan berdasarkan hasil evaluasi para ahli bahwa produk pengembangan media pembelajaran jujitsu newaza berbasis articulate storyline untuk PBJI Kabupaten Blitar ini dinyatakan memiliki ketepatan, kemenarikan, kesesuaian, kemudahan, kejelasan, dan keefektifan untuk digunakan oleh atlet sebagai media pembelajaran jujitsu newaza kemudian diberikan dan digunakan oleh atlet PBJI Kabupaten Blitar. Hal ini menunjukkan bahwa produk media pembelajaran jujitsu newaza dinyatakan memiliki kemenarikan, ketepatan, kesesuaian, kejelasan dan kemudahan. Oleh karena itu produk pengembangan layak digunakan oleh atlet sebagai media pembelajaran jujitsu newaza.

\section{Daftar Rujukan}

Arwanda, P., Irianto, S., \& Andriani, A. (2020). Pengembangan Media Pembelajaran Articulate Storyline Kurikulum 2013 Berbasis Kompetensi Peserta Didik Abad 21 Tema 7 Kelas Iv Sekolah Dasar. AlMadrasah: Jurnal Pendidikan Madrasah Ibtidaiyah, 4(2), 193. https://doi.org/10.35931/am.v4i2.331

Irawan, D., \& Japarianto, E. (2013). Analisa pengaruh kualitas produk terhadap loyalitas melalui kepuasan sebagai variabel intervening pada pelanggan restoran por kee surabaya. Jurnal Manajemen Pemasaran, 1(2), 1-8.

Kurniawan, A. W. (2014). Pengembangan Pembelajaran Judo Teknik Bantingan Kyu 4 dengan Media VCD untuk Pejudo PJSI (Persatuan Judo Seluruh Indonesia). Gelanggang Pendidikan Jasmani Indonesia, 2(1), 1017.

Listyawati, M. (2013). Pengembangan Perangkat Pemebelajaran Ipa Terpadu Di SMP. Journal of Innovative Science Education, 1(1).

Lukman. (2020). Pengurus Besar Jujitsu Indonesia (PBSI). Dalam https://penjasology.web.id/jujitsu/ diakses pada 28 agustus 2020.

Mcneil, S. (2015). Visualizing Mental Models : Understanding Cognitive Design and Development. Educational Technology Research And Development. 63(1), 73-96.

Pamungkas, I. A., \& Dwiyogo, W. D. (2020). Pengembangan Media Pembelajaran Berbasis Mobile Learning Untuk Aktifitas Kesegaran Jasmani Siswa kelas X Sekolah Menengah Kejuruhan. Sport Science and Health, 2(5), 272-278

Pratama, R. A. (2018). Media Pembelajaran Berbasis Articulate Storyline 2 Pada Materi Menggambar Grafik Fungsi Di SMP Patra Dharma 2 Balikpapan. Jurnal Dimensi, 7(1), 19-35.

Purnama, S., \& Asto, B. (2014). Pengembangan Media Pembelajaran Interaktif Menggunakan Software Articulate Storyline Pada Mata Pelajaran Teknik Elektronika Dasar Kelas X TEI 1 Di SMK Negeri 2 Probolinggo. Jurnal Pendidikan Teknik Elektro, 3(2), 275-279. http://dx.doi.org/10.17977/um003v3i22017p145 
Rasang, F. (2019). Analisis Gerak Cabang Olahraga Diving. Surabaya : Universitas Negeri Surabaya.

Puspitasari, dkk. (2018). Pengaruh Penggunaan Media Pembelajaran terhadap Motivasi Belajar Mahasiswa IKIP Siliwangi. Jurnal Pendidikan Bahasa dan Sastra Indonesia 1(2) 227-232.

Rachmadtullah, R. M. S. Z., Ms, Z., \& Sumantri, M. S. (2018). Development of computer-based interactive multimedia: study on learning in elementary education. Int. J. Eng. Technol, 7(4), 2035-2038.

Rahman, Z., Kurniawan, A. W., \& Heynoek, F. P. (2020). Pengembangan Pembelajaran Kebugaran Jasmani Unsur Kecepatan Berbasis Multimedia Interaktif. Sport Science and Health, 2(1), 78-92.

Roni, M., \& Ihsan, N. 2018. Pengaruh Latihan Uchikomi Karet terhadap Pengembangan Kemampuan Teknik Bantingan Tai Otoshi Atlet Judo PPLP Sumbar. Jurnal Pendidikan Dan Olahraga, 1(1), 114-118.

Setyaningsih, S., Rusijono, \& Wahyudi, A. (2020). Pengaruh Penggunaan Media Pembelajaran Interaktif Berbasis Articulate Storyline Terhadap Motivasi Belajar Dan Hasil Belajar Siswa Pada Materi Kerajaan Hindu. Jurnal Pendidikan dan Ilmu Pengetahuan, 20(2), 144-156.

Sugiyono. (2015). Metode Penelitian Pendidikan. Bandung: Alfabeta.

Sugiyono. (2014). Metode Penelitian Manajemen. Bandung: Alfabeta.

Wati, E. I., Ilyas, M., \& Sulistyowati, E. D. (2017). Pengembangan Media Mobile Learning dalam Pembelajaran Menulis Deskripsi pada Siswa Kelas X SMK. Ilmu Budaya: Jurnal Bahasa, Sastra, Seni dan Budaya, 1(4), 291-304.

Widoyoko, E. P. (2013). Evaluasi Program Pembelajaran. Jurnal Cakrawala Pendidikan, 5(1), 1-16. https://doi.org/10.21831/cp.v5i1.1266

Yumini, Si., \& Rakhmawati, L. 2015. Pengembangan Media Pembelajaran Interaktif Berbasis Articulate Storyline Pada Mata Diklat Teknik Elektronika Dasar Di Smk Negeri 1 Jetis Mojokerto. Jurnal Pendidikan Teknik Elektro, 4(3), 845-849. 